\title{
DESTINASI WISATA RELIGI: SOLUSI PENINGKATAN PEREKONOMIAN PELAKU WISATA DI KUDUS
}

\author{
Moh. Rosyid \\ Sekolah Tinggi Agama Islam Negeri Kudus \\ mrosyid72@yahoo.co.id
}

\begin{abstract}
Abstrak
Stabilnya sumber perekonomian warga merupakan tugas utama pemerintah dalam mewujudkan kesejahteraan. Dalam konteks Kota Kudus, semakin muramnya industri kretek karena ragam kebijakan yang menghimpit, Pemkab Kudus perlu mengoptimalkan sumber ekonomi lain sebagai penopang kehidupan warga. Destinasi wisata merupakan alternatif utama yang perlu dioptimalkan agar penopang sumber ekonomi terwujud. Bentuk riil yang harus dilakukan Pemkab Kudus memberi kemudahan dalam hal (1) akses permodalan, (2) pembangunan infrastruktur, (3) ketersediaan area wisata yang nyaman, (4) pembekalan dalam peningkatan sumber daya kepariwisataan, (5) publikasi, dan (6) terwujudnya keamanan dan kenyamanan wisatawan. Upaya ini perlu dievaluasi dengan melibatkan unsur pemerintah daerah, pemerhati wisata, akademisi, dan tokoh masyarakat agar kinerja dan produktivitas destinasi wisata berjalan optimal. Pelibatan investor dan industriawan juga perlu dioptimalkan sebagai 'bapak asuh' program kerja kepariwisataan. Kekompakan semua elemen dan stakeholders dunia pariwisata merupakan modal utama terciptanya perekonomian warga Kudus di tengah muramnya industri kretek.
\end{abstract}

Kata Kunci: pariwisata, ekonomi rakyat, dan kebijakan.

\section{A. PENDAHULUAN}

Dalam upaya meningkatkan investasi yang berimbas terhadap terbukanya lapangan usaha, pemerintah membuka secara luas peluang investor asing untuk berinvestasi di Indonesia pada 2014. Catatan Harian Kompas upaya tersebut berupa (1) investor asing bidang perbankan asetnya sebesar 50,6\%, setidaknya 12 bank swasta dimiliki investor asing seperti ANZ Banking Group Limited $99 \%$, Bank UOB Indonesia 98,84 \%, HSBC Asia Pacifik Holdings (UK) Limited 98,96 \%, CIMB Niaga 97,93 \%, OCBC Overseas Investmen 85,06 \%, (2) bidang pertambangan; migas $70 \%$, batubara, bauksit, nikel, dan timah $75 \%$, tembaga dan emas $85 \%$. Perusahaan asing tersebut Chevron, Conoco, Freeport, dan Newmont dari Amerika, sedangkan Total dari Perancis, dan Petrochina dari China, dan Freeport. Freeport merupakan perusahaan emas raksasa dunia asal Amerika menguasai saham 90,64 \% saham Freeport Indonesia. Pada 7/11/2013 Freeport melepas 15,64 \% saham, 
sebanyak 10,64 persen di antaranya dijual pada pemerintah RI. Freeport menyetorkan pada pemerintah RI per semester I 2013 dengan royalti 56 juta dollar AS, PPh badan 193 juta dollar AS, dan pajak lainnya 97 juta dollar AS (Jawa Pos, 8/11/2013, hlm.5), (3) bidang telekomunikasi; $35 \%$ dikuasai Sing Tel dari Singapura, 66,5 \% dikuasai XL Axiata Berhad dari Malaysia, Indosat $65 \%$ dikuasai Ooredo Asia dari Qatar, Hutchison Tri 60 \% dikuasai Hutchison Whampoa dari Hongkong, (4) perkebunan kelapa sawit; $40 \%$ dari 8,9 juta ha perkebunan kelapa sawit di Indonesia dikuasai investor asing seperti Guthrie, Golden Hope, dan KL Kepong dari Malaysia; Wilmar International dari Singapura; Cargill dari Amerika, dan SIPEF dari Belgia. Adapun sektor bisnis yang dibuka untuk asing (1) operator bandara dikelola $100 \%$, (2) periklanan mencapai $51 \%$, (3) jasa kendaraan mencapai $49 \%$, (4) terminal darat untuk barang mencapai $49 \%$, dan (5) pelabuhan mencapai 49 \% (Kompas, 7/11/2013, hlm.1).

Di balik upaya mempermudah investasi asing tersebut, kekhawatiran dominasi asing berimbas terhadap kedaulatan bangsa dalam keleluasaan dominasi asing di bidang investasi, ekonomi, dan pasar. Terutama adanya mobilitas pekerja antarnegara semakin tinggi saat pasar tunggal Masyarakat Ekonomi ASEAN (MEA) efektif beraku pada 1 Januari 2015. Menurut Wakil Ketua Badan Nasional Sertifikasi Profesi, Sumarna Indonesia menghadapi tantangan kesiapan pekerja terampil. Di sektor jasa, baru pekerja bidang pariwisata yang siap bersaing dengan pekerja dari negara ASEAN, sedangkan tenaga kerja di bidang kesehatan, logistik, telekomunikasi, dan transportasi udara belum siap bersaing di pasar regional. Hal ini harus mendapat prioritas untuk meningkatkan kualitas dengan mengembangkan sistem pendidikan berbasis kompetensi. Adapun beberapa profesi berdasarkan kesepakatan yang diakui bersama anggota ASEAN (Mutual Recognition Arrangement/MRA) untuk saling mengakui/menerima/ beberapa/semua aspek hasil penilaian. Profesi itu meliputi dokter gigi, dokter dan dokter spesialis yang teregistrasi, perawat, akuntan, insinyur, dan arsitek (Kompas, 15/11/2013, hlm.19). Di sisi lain, industry paat karya yang menyediakan lapangan kerja terkikis oleh ragam faktor, sebagaimana industry kretek.

\section{Peta Data}

Di tengah ketatnya pemerintah memberantas penggunaan cukai illegal, hal ini berdampak menyusutnya lahan kerja bagi industri rokok (kecil) yang tak taat asas. Bahkan lahan kerja bagi pekerja industri rokok yang legal makin terancam dengan diberlakukannya Permenkeu Nomor 181/PMK.011/2009 tentang Tarif Cukai Hasil Tembakau. Hal ini dirasa memberatkan bagi industri rokok golongan tiga. Keterpurukan ditambah adanya UU Nomor 36 Tahun 2009 tentang Kesehatan. UU ini ditindaklanjuti dengan PP tentang Pengamanan Produk Tembakau sebagai Zat Adiktif bagi Kesehatan. Muatan UU melarang iklan, promosi, dan sponsor produk mengandung tembakau (rokok). PP tersebut RPP-nya telah diserahkan pada Kementerian Hukum dan HAM 15 Januari 2010 untuk proses harmonisasi dan kini menjadi PP yang garang. Jika merujuk PP Nomor 19 Tahun 2003 bahwa iklan rokok 
di media elektronik masih 'dihalalkan' pada pukul 21.30 s.d 05.00 , tetapi PP tersebut produk tembakau tidak boleh diiklankan di semua jenis media (elektronik maupun cetak) maupun media luar ruang. Importir pun dilarang menjadi sponsor sebuah kegiatan, bahkan tanggung jawab sosial perusahaan (CSR) tidak boleh dilakukan yang bertujuan untuk mempromosikan atau mengenalkan produk tembakau. Diperkuat lagi adanya larangan bagi orang yang menjual produk tembakau melalui mesin layan diri, kepada konsumen di bawah umur 18 tahun, kepada perempuan hamil secara eceran, produk harus izin bidang perindustrian dan dilarang mengemas kurang dari 20 batang. Kondisi kini, dampak semua itu, terjadi gulung tikar 100 pabrik rokok di wilayah eks-karisidenan Pati yakni Kudus, Jepara, Pati, Rembang, dan Blora Jawa Tengah (Kompas, 21/11/2009). Bahkan data Dinas Perindustrian dan Perdagangan Kab. Jepara, sedikitnya 800 pekerja kehilangan mata pencaharian sebagai pekerja rokok rumahan karena gulung tikar, yang semula terdapat 1000 perusahaan rokok rumahan, kini tersisa 140 perusahaan (Suara Merdeka, 10 Desember 1009). Pemerintah pun menuai panen dengan menerima pemasukan cukai negara dari rokok hingga pekan pertama bulan Desember 2009 sebesar Rp 13,7 triliun (Suara Merdeka, 8/12/2009).

Di sisi lain, Kota Kudus dengan topografi daerah rendah (pertanian) dan daerah pegunungan yang menghasilkan buah-buahan jenis musiman, seperti durian, mangga, ace, dsb. perlu pemberdayaan. Hasil bumi tersebut jika tidak difasilitasi oleh pemerintah Kabupaten Kudus dalam bentuk kemudahan permodalan, menata sentra industri, promosi, dan prasarana pemasaran dikhawatirkan tidak menyejahterakan masyarakatnya (yang berancang-ancang meninggalkan industri rokok. Hal ini dapat memanfaatkan dana bagi hasil cukai yang pada tahun 2008 mencapai Rp 17,2 miliar dan tahun 2009 mencapai 72 miliar. Mengulas permodalan, Bank Jateng Wilayah Kudus tahun 2010 mengucurkan dana miliaran rupiah untuk penguatan Usaha Mikro Kecil dan Menengah (UMKM) yang diberikan dalam bentuk bantuan permodalan kepada pelaku usaha (Suara Merdeka,15/2/2010). Dalam hal ini Pemkab. Kudus harus mengokohkan dengan mitra perbankan tersebut. Kaitannya dengan lahan produksi telah dimiliki oleh masyarakat (khususnya) di wilayah Kecamatan Dawe dan lainnya agar diberi sentuhan oleh dinas perkebunan/pertanian agar kualitas produksi lebih baik. Adapun lahan promosi perlu digiatkan oleh dinas perindustrian/perdagangan melalui show produk dengan anjangsana dalam forum pameran produksi daerah atau nasional agar popularitas durian, mangga, ace, dsb. produk rasa khas Kota Kudus dapat tersosialisasikan pada publik. Harapan ke depan berupa tercipta dengan kokohnya sumber perekonomian rakyat kecil untuk mempersiapkan diri 'ketatnya' kebijakan pemerintah dan eksesnya dalam 'menangkal' industri rokok. Fasilitas tersebut diharapkan dapat memperkokoh eksistensi Kota Kudus sebagai kota wisata religi dan kota oleh-oleh (buah tangan) khas, sehingga ikon keduanya menjadi lestari dan mensejahterakan masyarakatnya.

Perekonomian wong cilik di Kudus akan muram bila sumber ekonominya hanya mengandalkan industri rokok. Data Forum Masyarakat Industri Rokok se- 
Indonesia (Formasi) bahwa dampak peta jalan (road map) industri tembakau tahun 2007 s.d 2020, pada tahun 2014 diprediksi pabrikan kecil rokok akan hilang. Penyebabnya karena:

Pertama, industri rokok level besar memproduksi rokok kelas kecil. Secara pelan dan pasti menyingkirkan kemampuan pabrik rokok kelas kecil, meskipun hal ini tidak bertentangan dengan regulasi pembuatan pabrik rokok. Akan tetapi, bagi perusahaan rokok kelas kecil, dibatasi minimal $200 \mathrm{~m}$ luas area industrinya berdasarkan Permenkeu Nomor 200 Tahun 2008. Solusi yang dilakukan Pemkab Kudus adalah memuat Lingkungan Industri Kecil (LIK) khusus industri rokok. LIK bersumber dari Dana Bagi Hasil Cukai (DBHC) tahun 2009-2010 Rp 22,38 miliar. LIK IHT di bawah naungan Koperasi Tobacco Kudus Sejahtera yang dibangun untuk industriawan rokok skala kecil/gol III (produksi 350-500 juta batang per tahun), sejumlah 11 brak, disediakan perangkat uji (lab tar dan nikotin), instalasi pengelolaan air limbah (IPAL). Lab tersebut apakah selalu ada pada industri rokok besar? LIK harus berizin HO (hinderor donnantie), surat izin gangguan. Pemilik LIK harus membeli cukai awal dengan modal awal 3 miliar, meskipun LIK hanya menyerap 10 \% (1.100 pekerja rokok), tahun 2012 baru menyerap 127 tenaga kerja.

Kedua, kenaikan harga pita cukai berdasarkan kebijakan dari Badan Kebijakan Fiskal, Kemenkeu, yang bersifat down to earth. Hal tersebut menimbulkan berkurangnya jumlah pekerja rokok. Sebagaimana pada tahun 2010, Data dari Pengurus Cabang (PC) Serikat Pekerja Rokok Tembakau, Makanan, Minuman (RTMM) Kudus 2012 jumlah pekerja rokok di Kudus tercatat 100 ribu pekerja. Akan tetapi, pada Februari 2012 tersisa 72 ribu pekerja, 28 ribu PHK. Di sisi lain, Upah Minimum Kota (UMK) Kudus tahun 2012 sebesar Rp 889 ribu/bulan. UMK pekerja rokok Rp 891 ribu (lebih besar 2 ribu). Hal itu berdasarkan kesepakatan PC Federasi Serikat Pekerja Rokok Tembakau Makanan dan Minuman (FSP RTMM) dengan Persatuan Perusahaan Rokok Kudus (PPRK). Meskipun teknis pengupahan pekerja rokok ada yang dengan pola borongan atau bulanan dengan sistem kerja outsourching/kontrak. Menurunnya jumlah pabrik rokok imbas kebijakan global berupa tudingan AS pada World Trade Organization (WTO) terhadap Indonesia karena mendiskriminasikan rokok kretek AS. Imbasnya dibatasi jumlah ekspor rokok Indonesia ke AS. Akan tetapi, Dispute Settlement Body WTO pada 2 September 2011 memenangkan Indonesia terhadap gugatan AS (Technical Barries to Trade). Selanjutnya AS pada 5 Januari 2012 menyampaikan notifikasi banding (keberatan) pada Appellate Body terhadap putusan WTO. Kekecewaan AS, ia memproduksi rokok bebas tembakau (elektrik). Meskipun tidak mendapat respon positif dari konsumen (perokok). Bahkan Michail Blomberg, wali kota Los Anggeles, produsen makanan sehat AS yang diekspor ke Indonesia, menuding, besarnya biaya pengeluaran warga Indonesia untuk rokok. Dengan demikian, warga AS dilarang mengimpor rokok kretek dan menghalalkan peredaran rokok menthol.

Menurunnya 'aroma' tembakau tidak hanya gencetan dari luar negeri, tetapi juga dari dalam negeri berupa, Pertama, naiknya harga bahan baku rokok tahun 2012 bahwa tembakau Rp 400 ribu per kg, cengkih Rp 100-120 ribu per kg, dan 
harga kertas yang variatif. Kedua, kenaikan harga pita cukai rokok tahun 2012 mencapai 16,5 \% dari harga pita cukai tahun 2011. Sehingga $30 \%$ income pengusaha rokok kelas kecil hanya untuk upah buruh dan biaya operasional, $70 \%$ untuk membayar cukai. Imbasnya muncul rokok bodong. Ketiga, fatwa pengharaman rokok oleh komisi Fatwa PB Muhammadiyah (perlu kajian lebih lanjut). Keempat, pemberlakuan UU Nomor 36 Tahun 2009 tentang Kesehatan bahwa rokok/kategori zat adiktif. Pasal 113 (2) zat adiktif berupa tembakau, produk yang mengandung tembakau: padat, cair, gas yang bersifat adiktif penggunaannya dapat menimbulkan kerugian bagi dirinya atau masyarakat sekitarnya. Lembaga Penyuluhan dan Bantuan Hukum (LPBH PBNU) menggugat Pasal 113 agar petani tidak resah dan tidak takut menanam tembakau karena tembakau tidak setara dengan ganja dan regulasi yang merugikan rakyat harus disisir. PBNU siap men-judicial review RPP Pembatasan Tembakau jika telah disahkan.

Meski terdapat pasal yang 'diculik' oleh oknum Komisi IX DPR RI (Ribka Tjiptaning, Aisyah Salekan, Mariani A Baramuli). Kasus tersebut telah di SP3-kan (dihentikan penyidikan) oleh Direktur I Keamanan Trans Nasional Bareskrim Polri. Kelima, Usulan Gubernur Jawa Tengah (saat itu) bahwa Jawa Tengah adalah desa bebas rokok dengan hadiah seekor sapi. Bahkan pernyataan Bibit, warga tidak usah ribut terhadap kenaikan BBM yang hanya sebesar Rp 1.500 (setara harga 2 batang rokok). Pernyataan Pak Bibit direspon dalam bentuk demonstrasi yang dilakukan oleh 350 petani tembakau dari Temanggung dan Kendal yang tergabung dalam Laskar Kretek, ketika Gubernur hadir di Temanggung. Pernyataan Gubernur dinilai menyakiti hati petani tembakau (Suara Merdeka, 3/5/2012). Kondisi kini dari dampak semua itu, terjadi gulung tikar 100 pabrik rokok di wilayah eksKarisidenan Pati yakni Kudus, Jepara, Pati, Rembang, dan Blora. Data Dinas Perindustrian dan Perdagangan Kabupaten Jepara, sedikitnya 800 pekerja kehilangan mata pencaharian sebagai pekerja rokok rumahan karena gulung tikar, yang semula terdapat 1000 perusahaan rokok rumahan, kini tersisa 140 perusahaan (Suara Merdeka, 10/12/2009). Pemerintah pun menuai panen dengan menerima pemasukan cukai negara dari rokok hingga pekan pertama bulan Desember 2009 sebesar Rp 13,7 triliun (Suara Merdeka, 8/12/2009). Sektor pembagian hasil cukai tahun 2011: Satpol PP Kudus menerima dana Rp 600 juta dan Kantor Pengawasan dan Pelayanan Bea dan Cukai Kudus (KPPBC Tipe Madya) Rp 300 juta -yang mengawasi cukai illegal-. Bila dirunut dalam UU No.39/2007 tentang Cukai bahwa dana cukai dipergunakan untuk peningkatan kualitas bahan baku (tembakau), pembinaan industri, pembinaan lingkungan sosial, sosialisasi ketentuan bidang cukai, pemberantasan barang kena cukai illegal.

Muramnya pekerja rokok tersebut Pemkab Kudus mengatasi PHK pabrikan rokok (khususnya) dengan mengoptimalkan Balai Latihan Kerja (BLK Disnakertrans Kudus) dengan fasilitas berlatih menjahit, pertukangan, perkayuan, tata boga, tata busana. Pada tahun 2012 melatih 5 ribu korban PHK. Usaha bijak yang bersumber dari dana cukai rokok oleh BLK Disnakertrans tersebut tidak 
mampu secara utuh mensejahterakan sumber perekonomian korban PHK rokok dan industri lain di Kudus. Lantas bagaiman nasib pekerja yang di PHK selanjutnya?

\section{B. PEMBAHASAN}

\section{Langkah Riil}

Kota Kudus dengan topografi daerah rendah (pertanian padi) dan daerah pegunungan yang menghasilkan buah-buahan jenis musiman seperti durian, mangga, ace, dsb. Hasil bumi tersebut jika tidak difasilitasi oleh pemerintah Kabupaten Kudus dalam bentuk kemudahan permodalan, menata sentra industri, promosi, dan prasarana pemasaran dikhawatirkan tidak mensejahterakan masyarakatnya yang berancang-ancang meninggalkan industri rokok (?).

Langkah riil yang perlu diwujudkan Pemkab Kudus adalah, Pertama, memanfaatkan dana bagi hasil cukai untuk pengembangan Usaha Kecil dan Menengah (UKM). Pada tahun 2008 mencapai Rp 17,2 miliar dan tahun 2009 mencapai 72 miliar. Sebagaimana sumber permodalan oleh Bank Jateng Wilayah Kudus tahun 2010 mengucurkan dana miliaran rupiah untuk penguatan Usaha Mikro Kecil dan Menengah (UMKM) yang diberikan dalam bentuk bantuan permodalan kepada pelaku usaha (Suara Merdeka,15 Desember 2010). Dalam hal ini Pemkab. Kudus harus mengokohkan dengan mitra perbankan tersebut. Kaitannya dengan lahan produksi telah dimiliki oleh masyarakat (khususnya) di wilayah Kecamatan Dawe dan lainnya agar diberi sentuhan oleh dinas perkebunan/pertanian agar kualitas produksi lebih baik. Adapun lahan promosi perlu digiatkan oleh dinas perindustrian/perdagangan melalui show produk dengan anjangsana dalam forum pameran produksi daerah atau nasional agar popularitas durian, mangga, ace, dsb. sebagai produk rasa khas Kota Kudus dapat tersosialisasikan pada publik. Harapan ke depan berupa tercipta dengan kokohnya sumber perekonomian rakyat kecil untuk mempersiapkan diri menghadapi 'ketatnya' kebijakan pemerintah dan eksesnya dalam 'menangkal' industri rokok. Fasilitas tersebut diharapkan dapat memperkokoh eksistensi Kota Kudus sebagai kota wisata religi dan kota oleholeh (buah tangan) khas, sehingga ikon keduanya menjadi lestari dan mensejahterakan masyarakatnya. Kedua, potensi lokal di Kudus yang bersumber dari kearifan alam berupa situs arkeologi bidang fosil di Pati Ayam, Desa Terban, Kecamatan Jekulo agar segera di-go publik dengan suntikan dana yang segar. Alokasi dana untuk mengembangkan situs Pati Ayam tahun 2012 hanya Rp 40 juta yang berada dalam pos anggaran pengelolaan dan pengembangan pelestarian peninggalan purbakala, museum, dan situs pati ayam (Suara Merdeka, 4 Februari 2012). Imbas minimnya sumber pendanaan, penjaga dan pemelihara (juru pelihara) enda Cagar Budaya (BCB) situs pati ayam mendapatkan upah Rp 75 ribu per bulan (Kompas, 8 Februari 2012). Ekowisata tersebut sebagai ciri khas untuk mengundang wisata alam tidak 
hanya wisatawan domestik tetapi juga mancanegara. Ketiga, karya kuliner lokal khas Kudus seperti Lentog Tanjung, bubur jagung dari Desa Menawan, Kecamatan Gebog, dsb. Keempat, yang lebih utama lagi adalah kearifan lokal (local wisdom) yang diwariskan oleh leluhur dapat dikemas lebih dinamis sesuai selera konsumen masa kini. Sebagaimana produk lokal khas Muria Kudus yakni Parijoto yang perlu dikembangkan secara luas dengan mengemas produk lebih mutakhir. Belum lagi jeruk khas Muria Kudus, kayu pengusir tikus yang dihasilkan dari area Gunung Muria. Belum lagi situs budaya religius yang dimiliki Kota Kudus karena kiprah Sunan Kudus dan Sunan Muria yakni Masjid al-Aqsha dan Menara Kudus-nya, Masjid Muria dan situs Makam Syekh Sadzali di Rejenu, Desa Japan Kecamatan Dawe Kudus.

Karya budaya leluhur tersebut dapat diberdayakan dengan memahami lima kata kunci membangun Kudus sebagai kota wisata, berupa (1) melindungi kebudayaan (protect the culture), (2) melindungi alam (Protect the nature), (3) memberdayakan dan menguntungkan masyarakat (empower and bring benefit to local people), (4) melakukan konservasi (conservation) lingkungan fisik dan nonfisik, dan (5) menciptakan lahan eksotis yakni daya tarik wisata khas dan belum banyak dikenal/dimiliki obyek wisata tempat lain. Kelima konsep tersebut memerlukan kepedulian yang besar dari Pemkab Kudus mulai dalam bentuk pendanaan, supporting/motivasi mengembangkan kearifan lokal, dan pemberdayaan pelaku wisata dan pelaku usaha berbasis kearifan lokal.

Lima kata kunci membangun Kudus sebagai kota wisata yang ditopang dengan membangun karakter warga Kudus sejak di bangku sekolah dalam bentuk pengenalan kearifan lokal berupa kurikulum muatan lokal (mulok) dan memberdayakan wisata religi. Mengapa? Menanamkan cinta berbudaya dijadikan sebagai semangat dasar agar pelaku budaya mengenal, memahami, dan mencintai sepenuh hati. Kebudayaan diibaratkan sebagai tempat (wadah, contour) dan pendidikan dimisalkan sebagai bahan (content) yang menempati (diwadahi). Dengan tempat yang ideal, diharapkan tercipta generasi yang berbudaya (beretika), bertata laku (conduct) bijak, dan menempati tempat (kebudayaan) yang ideal pula, karena keduanya tidak dapat dipisahkan. Hal tersebut menandaskan bahwa generasi yang berbudaya tercipta setelah digodok di lembaga pendidikan. Jika tidak terwujud, berarti pendidikan telah gagal mencetak generasi terdidik, sebagaimana tertuang dalam UU Nomor 20 Tahun 2003 Pasal 3 pendidikan nasional berfungsi mengembangkan kemampuan dan membentuk watak serta peradaban bangsa yang bermartabat (berharga diri) dalam rangka mencerdaskan kehidupan bangsa. Pendidikan pun memiliki tujuan baku, untuk mewujudkannya, keberadaan muatan lokal selazimnya dikokohkan keberadaannya beserta evaluasi yang melekat dan berkesinambungan. UU Nomor 20 Tahun 2003 Pasal 1 (2) Pendidikan nasional adalah pendidikan yang berdasarkan Pancasila dan UUD Negara Republik Indonesia Tahun 1945 yang berakar pada nilai-nilai agama, kebudayaan nasional Indonesia dan tanggap terhadap tuntutan perubahan zaman dan Pasal 
4 (1) Pendidikan diselenggarakan secara demokratis dan berkeadilan serta tidak diskriminatif dengan menjunjung tinggi HAM, nilai keagamaan, nilai kultural, dan kemajemukan bangsa. Pasal 37 ayat 1 (g) Kurikulum pendidikan dasar dan menengah wajib memuat seni dan budaya.

Strategi mengeksiskan budaya dan kebudayaan adalah melalui jalur pendidikan yakni penanaman nilai budaya secara teoretis diimbangi pemahaman secara praktis yang tercermin dalam tujuan pembelajaran, meliputi (a) tujuan pendidikan nasional (tujuan yang sifatnya umum, jangka panjang dan didasari falsafah negara), (b) tujuan institusional/lembaga, ingin dicapai setiap lembaga pendidikan, (c) tujuan kurikuler, yang ingin dicapai setiap bidang studi, dan (d) tujuan instruksional/pembelajaran, tujuan yang ingin dicapai setiap akhir bab (subbab).

\section{Langkah Antisipasi}

Bila Pemkab Kudus menyadari bahwa murungnya perekonomian warga Kudus berdasarkan data perhitungan Badan Pusat Statistik (BPS) Kabupaten Kudus awal tahun 2012, rumah tangga miskin di Kudus mencapai 68.379 rumah tangga atau 35 persen dari sekitar 190 ribu rumah tangga. Jika tahun 2008 jumlah rumah tangga miskin hanya 35.502 yang menjadi obyek distribusi beras miskin (raskin). Raskin pada 2014 di Kudus sebanyak 36.332 rumah tangga sasaran (RTS) sebagaimana 2013 berdasarkan pendataan program perlindungan sosial 2011. Tiap RTS menerima jatah raskin $15 \mathrm{~kg}$ per bulan dengan harga tebus raskin Rp 1.600 per kg (Suara Muria, 4/1/2014, hlm.23). Bahkan hasil pantauan kegiatan survei Pendataan Program Perlindungan Sosial (PPLS) BPS Kudus akhir 2011, terdapat 1.026 rumah tangga sasaran yakni keluarga miskin (Suara Merdeka, 15 November 2011). Terdapat 52 Dukuh di 9 kecamatan di Kudus belum teraliri listrik (Radar Kudus, 10 Mei 2012). Program Keluarga Harapan (PKH) di Kudus 2014 terdapat 5.428 rumah tangga sangat miskin (RTSM) dari yang diusulkan 6.115 KK. RTSM berada di Kecamatan Kaliwungu 420 KK, Dawe 1.880 KK, Gebog 620 KK, Jekulo 144 KK, Jati 492 KK, dan Undaan 963 KK. Parameter miskin bila pendapatan per bulan di bawah Rp 500.000 dan keluarga yang memiliki anak balita, anak yang masih sekolah, ibu hamil dan ibu yang masih nifas. Bantuan tetap Rp 200.000 untuk pendidikan SD, pendidikan SMP Rp 800.000, dan bantuan kesehatan ibu dan bayi Rp 800.000. Di samping itu, usulan tambahan terhadap 2 ribu untuk Kecamatan Kota, Bae, dan Mejobo (Suara Muria, 9/1/2014, hlm.23). Hal tersebut akibat berbagai faktor di antaranya menurunnya jumlah industri rokok yang berpengaruh terhadap Pendapatan Asli Daerah (PAD) Kabupaten Kudus, seyogyanya memberdayakan potensi lokal berupa produk khas lokal Kudus dan pemberdayaan wisata religi yang dapat dijadikan alternatif utama lahan/sumber perekonomian warga Kudus. Realisasi PAD Kabupaten Kudus tahun 2011 tercapai Rp 108 miliar atau 
minus Rp 5,7 miliar dari target Rp 114 miliar. Untuk tahun 2012 alokasi PAD dianggarkan Rp 109,2 miliar dari target Rp 114 miliar (Suara Merdeka, 26 Januari 2012). Bila hal ini tidak terealisasi, dikhawatirkan antara anggaran dengan pendapatan di bidang pariwisata di Kudus akan terulang kembali merugi. Tahun anggaran 2010, sektor pariwisata Kabupaten Kudus dianggarkan Rp 7,42 miliar, tetapi pendapatan hanya Rp 840,3 juta saja (Radar Kudus, 16 Juli 2011).

Setiap program yang dilaksanakan oleh pemerintah dan berimbas terhadap kehidupan rakyat, perlu dilakukan evaluasi. Dalam konteks kepariwisataan, perlu mengaca terhadap kemegahan Bali di balik kemurungan wong cilik. Pembangunan hotel yang banyak dan megah sebagai bukti industri pariwisata di Bali eksis. Namun, apakah semua keuntungan dari pariwisata dapat dinikmati oleh warga masyarakat Bali kelas bawah? Tidak, mengapa? Karena pemodal kecil telah dilibas oleh investor global yang berdampak terpuruknya sumber ekonomi wong cilik. Hal ini disikapi oleh lembaga nonpemerintah yang bergerak dalam bidang perdagangan berkeadilan (fair trade). Sejak tahun 1993, mereka merangkul para perajin di Bali yang tersisih dan terdepak oleh kehadiran pelaku industri pariwisata yang bermodal besar, 85 persen aset pariwisata di Bali dimiliki investor dari luar Bali (Dewanto, 2011). Dengan demikian, orang Bali menjadi kuli di negeri sendiri. Hal ini telah diwanti-wanti oleh pendiri bangsa bahwa sejak prakemerdekaan telah menolak liberalisme dan individualisme yang menjadi roh kapitalisme. Kapitalisme inilah pada tahap berikutnya menjadi imperalisme, baik yang kasat mata maupun yang tidak nampak. Tidak nampaknya imperalisme dengan dalih investasi yang membuka kran lapangan kerja. Meskipun penentuan dan kebijakan yang berkaitan dengan hak buruh selalu dimenangkan oleh si kaya. Bung Hatta pada tahun 1928 menuding Pengadilan Den Haag dalam pledoinya "Indonesia Vrij", lebih baik Indonesia tenggelam ke dasar lautan daripada menjadi embel-embel bangsa lain. Bung Hatta memahami bahwa tahta adalah milik rakyat yang melahirkan konsep demokrasi ekonomi. Kemakmuran rakyat lebih utama daripada kemakmuran orang-per orang. Bahkan Bung Karno menggugat di Pengadilan Bandung pada tahun 1930 yang pledoinya (pembelaannya) berjudul "Indonesia Klaagt-Aan" bahwa imperialisme membuahkan negeri mandat. Selanjutnya pada sidang BPUPKI (Badan Pelaksana Usaha Persiapan Kemerdekaan Indonesia) 15 Juli 1945, Soekarno-Hatta menyatakan bahwa Negara Indonesia didirikan berdasarkan rasa kebersamaan, sehingga dijadikan paham bernegara berdasarkan asas kebersamaan dan kekeluargaan. Tahap berikutnya kita kenal koperasi, bukan mengundang investasi. Esensi koperasi adalah ekonomi paseduluran dengan prinsip saling mempercayai dan dapat saling dipercaya.

Sudah saatnya negara amanah terhadap UUD 1945 Pasal 33 (3) bumi, air, dan kekayaan alam yang terkandung di dalamnya dikuasai oleh negara dan dipergunakan untuk sebesar-besarnya kemakmuran rakyat. Berdasarkan data BPS, jumlah penduduk miskin per September 2013 mencapai 28,55 juta (11,47 
persen) bila dibanding 2013 hanya 28,07 juta. Dalam waktu enam bulan jumlah warga miskin sebanyak 480.000 penduduk. Faktor naiknya jumlah warga miskin menurut Kepala BPS Suryamin akibat (1) terjadinya inflasi sebesar 0,02 persen akibat kanaikan BBM pada Juni 2013, (2) kenaikan harga beras dan sembako, dan (3) meningkatnya jumlah pengangguran periode Februari-Agustus 2013 (Sindo, 3/1/2014, hlm.11).

Aspek lain yang perlu dikembangkan adalah mengembangkan program ekonomi kreatif. Majelis Ulama Indonesia (MUI) dan Kementerian Pariwisata dan Ekonomi Kreatif (Kemenparekraf) era Presiden SBY merealisasikan gagasan wisata syariah sejak Juni 2013. Di Indonesia ada 9 destinasi wisata yang berpotensi untuk dipromosikan sebagai destinasi wisata syariah yakni Sumbar, Riau, Lampung, Banten, Jakarta, Jabar, Jatim, Sulsel, dan NTB. Karakter wisata syariah di antaranya fasilitas hotel menyediakan musala, kamar hotel tersedia kitab suci, dapur halal, tak menjual minuman keras dan hotel tersrbut menerapkan prinsip syariah. Konsep ini merespon realitas bahwa penganut muslim sekitar 250 juta jiwa atau 88,1 persen dari jumlah penduduk Indonesia. Populasi muslim dunia 1,6 miliar jiwa. Uang yang dihabiskan wisatawan muslim di Indonesia pada 2011 mencapai 126 miliar dolar AS atau 1.227,9 triliun, angka ini lebih besar dari uang yang dikeluarkan oleh wisatawan Cina, AS atau Jerman. Begitu pula Pemprov Jateng berupaya mengoptimalkan pasar wisata syariah, khususnya mendatangkan wisatawan dari negara Islam. Produk wisata syariah tidak hanya berorientasi pada wisata religi juga menyangkut pelayanan seperti masakan halal, tempat beribadah, dsb. Industri kreatif meliputi periklanan, arsitektur, pasar barang seni, kerajinan, desain, fashion, video, film dan fotografi, permainan interaktif, musik, seni pertunjukan, tv dan radio, riset dan pengembangan, kuliner, layanan computer dan peranti lunak, penerbitan dan percetakan. Menurut Menteri Pariwisata dan Ekonomi Mari Elka Pangestu, subsektor industri kreatif tersebut, 3 subsektor yang berkonstribusi: kuliner (7,28 persen), fashion (5,60 persen), dan kerajinan (2,88 persen). Yang berkontribusi di bidang ekspor: fashion 3,69 persen, kerajinan 1,04 persen, dan kuliner 0,57 persen (Kompas, 31/12/2013, hlm.14).

\section{Pemberdayaan Situs Sejarah}

Lokasi Wisata Religi di Jateng antara lain Masjid Saka Tunggal di Cikakak, Banyumas. (2) Makam Syekh Maulana Maghribi, Wonobodro, Batang. (3) Makam K.Abdul Kohar, Desa Ngampel, Blora, (4) Makam Ki Hajar Saloka, Desa Samiran, Selo, Boyolali. (5) Makam Mbah Rubi Klampok, Brebes. (6) Makam K.Junaid, Randusanga, Brebes.(7) Gunung Srandil dan Gunung Selok, Karangbenda, Adipala, Cilacap, (8) Masjid Agung, Demak, (9) Makam Sunan Kalijaga, Kadilangu, Demak, (10) Makam Ki Ageng Selo, Tawangharjo, Grobogan. (11) Makam Ratu Kalinyamat, Mantingan, Jepara. (12) Makam Pangeran Hanggawana, Desa Kalisoka, Dukuhwaru, Slawi, (13) Goa Maria Kerep, Ambarawa, Kab.Semarang, (14) Makam al-Haddad, Desa Kraton, Tegal 
Barat, (15) Astana Giri Bangun, Desa Giri Layu, Matesih, Kabupaten Karanganyar dan Makam Pangeran Samber Nyawa, (16) Makam Ki Ageng Balak, Sukoharjo, (17) Makam Ki Ageng Pandanaran, Desa Paseban, Bayat, Klaten, (18) Makam Sunan Muria, Kudus, (19) Makam K.Dudo, Dukuh Dudan, Tidar, Magelang, (20) makam Syaridin, Syeh Jangkung, Landoh, Kayen, Pati, (21) Makam Sayid Ahmad, Kompleks TPU Sapuro, Pekalongan Barat, (22) Makam Syekh Syamsuddin, Desa Sugihwaras, Pemalang, (23) Petilasan Ardilawet, Desa Panusupan, Rembang, Purbalingga, (24) Bedug Pendowo Masjid Darul Muttaqin, alun-alun Purworejo, (25) Masjid Agung dan Kompleks Makam Adipati Rembang, (26) Makam Pangeran Samudro di Gunung Kemukus, Desa Pendem, Sumberlawang, Sragen.

Ke-26 destinasi wisata agama (penziarahan) tersebut, terdapat destinasi yang berada di Kudus, yakni Makam Sunan Muria di Gunung Muria dan Makam Sunan Kudus dan Masjid al-Aqsha di Kudus. Upaya Pemkab Kudus dalam optimalisasi kedua makam tersebut berupa fasilitasi perayaan hari bersejarah yang berkaitan dengan ritual di kedua makam. Sebagaimana setiap 10 Syura diadakannya buka luwur makam Sunan Kudus. Peristiwa ini perlu digencarkan dalam sosialisasi pada public untuk menarik calon peziarah (wisatawan).

Selain itu, terdapat situs bersejarah khas yang hanya ada di Kudus yakni Menara Masjid al-Aqsha. Menara Masjid Al-Aqsha berupa bangunan vertikal tinggi 18 m menyerupai Candi Jago di Jati dan Candi Menara (bentuknya seperti menara) yakni candi Hindu di Desa Candirenggo, Kecamatan Singosari, Malang, Jawa Timur sisa reruntuhan candi tahun 1800-an. Ahli purbakala Eropa WF Stutteirheim pernah menyebut candi tersebut Candi Cella karena beberapa bagian bangunan candi terdapat celah. Ada pula yang menyebut Candi Cungkup atau Candi Renggo karena berlokasi di Desa Candirenggo. Akhirnya disebut Candi Singosari karena berada di wilayah Kecamatan Singosari. Candi Singosari ditemukan pertama oleh Nicolaus Engelhard, Gubernur Pantai Timur Laut Jawa pada tahun 1803. Selanjutnya candi mendapat perhatian oleh orang Eropa antara lain Thomas Stamford Raffles. Pada 1934-1937 Departemen Survei Arkeologi dari Hindia Timur Belanda merestorasi Candi Singosari. Struktur Candi Singosari berupa mahakala, penjelmaan Dewa Siwa dan Nandiswara, penjelmaan Lembu Nandi yang menjadi dewa penjaga pintu masuk utama candi. Pada bagian atas pintu masuk ruang utama, ruang utara, ruang timur, dan ruang selatan terdapat hiasan kepala Kala atau Banaspati (Raja Hutan). Candi ini terbagi menjadi swahloka (puncak), bwahloka (badan), bhurloka (kaki), dan batur (bagian terbawah candi). Bagian utama candi merupakan lokasi arca Siwa Bhairawa. Sisi utara candi terdapat arca Durga atau Dewi Uma parwati, isteri Dewa Siwa. Sisi timur merupakan lokasi arca Dewa Ganesya, putra Dewa Siwa dengan Dewi Durga. Bagian selatan berisi arca Resi Guru atau Siwa Guru atau Resi Agastya. Para sejarawan menafsiri bahwa bentuk candi merupakan respon Sunan Kudus mengadopsi dan mengakulturasi karya budaya pemeluk 
Hindu. Keberadaan menara masjid berdasarkan inskripsi Arab Kuno yang terdapat di mihrab masjid Al-Aqsa, keberadaan masjid lebih dulu jika dibandingkan dengan menara. Masjid didirikan tahun 956 H/1549 M dan nama masjid tersebut adalah Al-Manar atau Al-Aqsa yang pernah direnovasi pada 1919, 1933, 1976, dan 1978.

Menara Masjid Al-Aqsa dengan pernik-pernik yang tertempel berupa keramik. Sakai Takashi dan Takimoto Tadashi, arkeolog Jepang menelusuri asal mula berbagai keramik di Masjid dan Menara Kudus pada 28 Agustus 2008 dikaitkan dengan agama dan peradaban. Menurutnya, dua di antara sekian banyak keramik di menara (menempel di atas 'pintu' bagian utara dan bagian selatan) buatan pabrik keramik di Vietnam abad ke-14 s.d 15, meski pabrik kini sudah tiada. Keramik di bagian utara berbentuk segi empat, berwarna dasar putih, di bagian tengah berwarna sedikit kebiruan dengan motif bunga berusia paling tua yakni awal abad ke-14 atau sekitar tahun 1450. Keramik di bagian selatan berbentuk lebih besar, lebih menarik, didominasi warna biru bermotif bunga 'berbau' vietnam dan bentuknya 'berbau' Islam. Motif ini bisa ditemukan di Istambul, umurnya lebih muda, menjelang atau awal abad ke-15. Pernik keramik sebagian besar di masjid menara umumnya buatan China tahun 1920an. Hubungan Kota Kudus dengan Asia Selatan terbukti ditemukannya 3 mangkok kuno, 2 berdiameter $15 \mathrm{~cm}$ dan tinggi $5 \mathrm{~cm}$, yang satunya berdiameter $14 \mathrm{~cm}$ dan miniatur rumah khas Melayu produk China abad 15 saat pedagang China singgah di Pantai Purwodadi (berbatasan dengan Desa Wonosoco Kudus). Mangkok ditemukan Sutodirono, warga Desa Wonosoco, Undaan, Kudus tahun 2000 di petilasan pertapaan Raden Mas Singgah (Sunan Kalijaga) di Pegunungan Kendeng, desa setempat. Pada 2009 diserahkan pada Dinas Pariwisata dan Kebudayaan Kabupaten Kudus sehingga perlu museum agar benda bersejarah terawat.

Kudus pun kaya dengan penemuan benda cagar budaya, meski penanganannya belum optimal oleh Pemda Kudus. Keramik berupa mangkok kuno dan miniatur rumah khas melayu produk China abad ke-15 sejumlah tiga buah ditemukan oleh Sutodirono, warga Desa Wonosoco, Undaan, Kudus tahun 2000. Benda ditemukan di petilasan/pertapaan Raden Mas Singgah (Sunan Kalijaga) di Pegunungan Kendeng, Wonosoco, Undaan, Kudus. Mangkok dan rumah khas tersebut diduga, saat pedagang China singgah di Pantai Purwodadi, berbatasan dengan Desa Wonosoco. Pada 2009 diserahkan pada Dinas Pariwisata dan Kebudayaan Kabupaten Kudus. Dua mangkok berdiameter $15 \mathrm{~cm}$ dan tinggi $5 \mathrm{~cm}$ dan diameter $14 \mathrm{~cm}$.

\section{Optimalisasi Destinasi Wisata}

Tim Balai Pelestarian Cagar Budaya (BPCB) Jawa Tengah pada 2014 melakukan pemugaran Menara Masjid Al-Aqsha Kudus melanjutkan pemugaran tahun 2011. Pemugaran pada 2013 bagian mustoko atau atap serta sirap dan mengganti 3.000 buah batu bata yang rapuh di 28 lapis. Pemugaran 
pada Mei 2014 merevitalisasi batu bata yang 80 persen rapuh diganti yang baru. Terdapat 10 ribu batu bata yang diganti karena rapuh. Teknik penggantian dengan cara konvensional, yakni mencopot satu per satu agar tidak mengganggu konstruksi. Pengerjaan dengan pola konsolidasi, yakni dari atas ke bawah karena medan yang sulit dan untuk kenyamanan peziarah. Untuk batu batu relief dan bentuk klasik yang kondisinya rusak atau hilang dilakukan repro agar tak menghilangkan nilai sejarah. Hasil temuan Tim Balai Pelestarian Cagar Budaya (BPCB) Jawa Tengah dalam pemugaran Menara Kudus bahwa penyebab terganggunya konstruksi menara karena getaran kendaraan bermotor yang melintas setiap hari. Koordinator pemugaran Menara dari BPCB Jawa Tengah, bahwa dilakukan penggantian batu bata menara yang sudah rapuh dan pembuatan peredam getaran di bawah samping pondasi. Jaraknya selebar satu meter digali dan diberi batu kali dengan cor semen (Suara Merdeka, 23 Mei 2014, hlm.21). Menara kini rentan dengan getaran kendaraan yang melintas di depan menara. Salah satu sudut konstruksi yang paling parah berada di sebelah timur yang letaknya berdekatan dengan akses jalan. Menurut tim, di sekitar Menara Kudus idealnya tidak diperkenankan untuk dilewati kendaraan bermotor karena menimbulkan getaran. Akan tetapi karena jalan tersebut digunakan warga penghuni di sekitar Menara, sehingga belum ada jalan keluar penyelesaian hingga pertengahan 2014. Dalam pengamatan penulis, jalan raya itu juga digunakan angkutan umum, mobil umum, dan mobil (non-bus) peziarah.

Pada Juni 2014 dilakukan pemugaran pada bagian bodi/tubuh menara bagian tengah hingga ke bawah. Pemugaran untuk mengganti 10.000 batang batu bata yang rapuh dengan cara konvensional. Menempelkannya batu bata dengan memanfaatkan pecahan batu bata yang dilembutkan dan gamping untuk menghindari efek penggaraman bila dari bahan semen. Kondisi menara terparah bagian tubuh di sebelah timur dengan tingkat kerusakan mencapai 60 persen karena getaran kendaraan yang lalu lalang. Menara Kudus berumur 500 tahun disiapkan 10.000 bata yang bentuk dan kualitasnya mirip dengan batu bata aslinya yang terpasang. Batu bata baru itu dipesan di Desa Pasuruan, Kecamatan Jati, Kudus yang terbuat dari tanah lempung asli tanpa campuran dengan ukuran panjang $31 \mathrm{~cm}$, lebar $15 \mathrm{~cm}$, dan tebal $5 \mathrm{~cm}$. Biaya pemugaran dari APBN tahun 2013 sebesar Rp 419,469 juta. Adapun anggaran APBN tahun 2014 Rp 300 juta (Koran Sindo, 6 Juni 2014, hlm.19).

Ornamen Menara Kudus berbentuk piring terbuat dari bahan keramik sebagian sudah tidak ada di tempat semula (hilang) dan ada yang masih menempel. Tetapi, pada pemugaran tahun 1980-an ada ornamen dipasang tidak sesuai dengan posisi aslinya. Metode pemasangan ornamen dengan adonan non-semen agar tidak terjadi penggaraman. Setelah sebulan pembongkaran, pada akhir Juni 2014 puluhan ribu batu bata Menara Kudus diperbaiki/diganti. Fase ini tim menghadapi masa sulit karena kondisi material (bata) lama (keberadaan sejak dulu) tingkat kerusakannya cukup parah bila dibandingkan 
dengan bagian sebelumnya yang telah dipugar. Batu bata lama yang ukurannya sudah tak beraturan dan banyak yang rapuh sehingga harus disusun lagi sebagaimana sediakala. Bila tidak berhati-hati, akan mengganggu konstruksi menara. Dalam mencopot batu bata lama dilakukan metode konvensional yakni mencopot satu per satu dari badan menara. Begitu pula tatkala menggantinya dengan batu bata yang baru. Bila memotong menggunakan mesin pemotong untuk efesiensi waktu dan hasilnya lebih bagus. Kendala yang dihadapi tim, ukuran batu bata yang akan digunakan mengganti bata lama tidak pas sehingga diganti yang lebih tebal. Semula tebalnya $4,5 \mathrm{~cm}$ diganti $7 \mathrm{~cm}$.

Pemugaran Menara Kudus pada tahap bulan April 2014 melibatkan 20-an pekerja dari tim Balai Pelestarian Peninggalan Purbakala (BP3) Jawa Tengah. Pemugaran juga pernah dilakukan pada 2002. Tingkat kerusakan Menara Kudus mencapai 90 persen, terutama pada tubuh bangunan yang menghadap ke timur sudah lapuk dan rusak. Hal ini menurut juru pugar dari Balai Peninggalan Cagar Budaya (BPCB) Jawa Tengah akibat getaran kendaraan bermotor yang melintas di depan Menara, faktor cuaca berupa sinar matahari dan guyuran air hujan yang prosesnya terakumulasi sehingga membuat material mudah rusak. Langkah yang dilakukan adalah mencopot semua batu bata di bagian kaki tubuh bangunan menara mulai dari terap pertama hingga terap ketiga. Pemugaran Menara Kudus pada Juni 2014 mencapai 40 persen, maknanya sebagian dari tubuh Menara Kudus menggunakan material baru dan lebih kuat. Hal itu tidak menghilangkan nilai sejarah karena tidak menghilangkan atau menambah bagian pada Benda Cagar Budaya (BCB). Fondasi Menara Kudus telah dipugar sebelum tahun 1980-an untuk menempatkan cor beton dengan kedalaman $50 \mathrm{~cm}$ sebagai penahan air agar tidak merembes ke bagian fondasi bawah yang masih menggunakan batu-bata. Menurut Tim Badan Peninggalan Cagar Budaya Jateng (BPCB), hasil penggalian fondasi pada September 2014, di sebelah selatan bangunan kedalaman fondasinya $190 \mathrm{~cm}$ terdiri 30 lapis batu bata. Sebelah utara sisi barat ukuran kedalaman fondasinya sama dengan sebelah selatan. Kedalaman fondasi gapura $80 \mathrm{~cm}$ dan fondasi pagar 1,5 m. Rata-rata fondasi hingga September 2014 masih normal dan tak ada masalah.

Hingga September 2014, pemugaran Menara Masjid Al-Manar Kudus mencapai 80 persen dari target 100 persen pada akhir 2014. Pada Minggu 7 September 2014 pemugaran Menara Kudus dikunjungi oleh tim arkeologi BPCB Jawa Tengah dan Dirjen Kebudayaan Kemendikbud Kacung Marijan. Memasuki bagian akhir pemugaran, tim Balai Peninggalan Cagar Budaya (BPCB) Jawa Tengah memperbaiki serta mengembalikan ornamen ukiran di bagian barat atau tepatnya di kanan dan kiri tangga menara. Begitu pula penyelesaian selasar bangunan dan konservasi (pemeliharaan) bagian atas Menara atau pilar penyangga atap yang berbahan material kayu. Bagian tubuh Menara disemprot dengan zat antilumut, untuk bagian atas diberi cairan berbahan dari rebusan tembakau dan cengkih. Kemudian dikuaskan pada empat pilar penyangga atap serta bagian lain yang berbahan material batu. Tujuannya agar material lama 
dan yang baru (pengganti) lebih awet dan tahan lama. Pada minggu ketiga September 2014 akan dilakukan pelepasan andang atau penyangga dari bambu yang sebelumnya digunakan sebagai alat bantu memanjat untuk memugar bagian tubuh Menara dalam proses renovasi. Pada awal Oktober direncanakan finising secara menyeluruh pada material yang terpasang. Pada pertengahan Oktober 2014 direncanakan pemugaran selesai.

Untuk memaksimalkan perawatan setelah pemugaran seluruh fisik bangunan Menara Masjid al-Aqsha Kudus, tim Balai Peninggalan Cagar Budaya (BPCB) Jateng berkonsultasi dengan pihak UPT Candi Borobudur terkait formula yang digunakan untuk merawat material Menara Kudus, khususnya penggunaan obat anti lumut yang tumbuhnya potensial pada musim penghujan, selain terdapat bahan kayu dalam Menara yang dirawat dengan cairan rebusan tembakau yang dicampur dengan bahan baku lainnya yang dikuaskan pada kayu. Sehingga minimal perawatannya tiga bulan sekali. Bila Borobudur menggunakan material batu andesit, sedangkan Menara Kudus menggunakan batu bata (Suara Merdeka, 30 Oktober 2014, hlm.23).

Kata 'Kudus' diciptakan oleh Sunan Kudus sepulang dari ibadah haji, dalam sebuah batu prasasti hadiah diperoleh Sunan Kudus dari Gubernur Palestina sewaktu ibadah haji. Batu bertuliskan kaligrafi Arab yang diletakkan di atas mihrob Masjid Menara Kudus bertuliskan tahun berdirinya Kota Kudus (956 H) tepatnya hari Senin 1 Ramadan $956 \mathrm{H}$ atau 22 September 1549 M yang ditetapkan sebagai hari jadi kota Kudus. Kudus dalam catatan VOC abad ke-17 posisinya berada di daratan pulau Jawa. Orang bisa berlayar keliling Gunung Muria dengan perahu kecil (Van Bemmelen). Dalam Map of Java yang diterbitkan Geraard van Kuelen edisi pertama 1728 M, Prof. Adriana Reland menyebut Gunung Muria de berg van Japara. Nama kata Kudus bersumber dari prasasti di atas mihrab Masjid Menara Kudus tertulis: Dengan nama Allah yang Maha Pengasih dan Maha Penyayang. Telah mendirikan masjid al-Aqsha ini di negeri Kudus, khalifah pada zaman ulama dari keturunan Muhammad untuk membeli kemuliaan surga yang kekal, untuk mendekat Allah di negeri Kudus. Membina masjid al-Manar yang dinamakan al-Aqsha khalifatullah di bumi, yang agung dan mujtahid yang arief, kamil fadhil al-maksud dengan pemeliharaan al-Qodli Ja'far Shodiq tahun 956 hijrah Nabi SAW. Keberadaan Masjid Al-Aqsa memiliki kekhasan berupa menara di halaman masjid, kompleks makam Sunan Kudus di belakang masjid, tempat wudlu (padasan) terdiri 8 pancuran (kran). Dalam ajaran Buddha, 8 kepala arca yang semula ada di 8 pancuran wudu Masjid al-Aqsha sebelum diperbaiki (sebagaimana kini) yang dikenal astasanghikamarga (asta: 8 , sanghika: berlipat, dan marga: jalan) yakni 8 jalan utama yang benar dalam hal pemgetahuan, keputusan, perkataan, perbuatan, cara penghidupan, daya usaha, meditasi, dan kontemplasi yang benar (suci, murni, luhur). Hal ini merupakan penafsiran dari teman penulis warga Kudus yang beragama Buddha.

Tajug tempat musyawarah Sunan Kudus (masa kini, khususnya bulan Ramadan digunakan mengaji kitab kuning di sore hari), gapura kembar (di 
halaman masjid) dan gapura padureksan (di luar masjid), gapura samping masjid, gapura tajug (sisi samping belakang masjid). Peninggalan Sunan Kudus yang masih dapat disaksikan dan agar terawat, oleh Pengurus Yayasan masjid dan Makam Sunan Kudus mendirikan museum mini. Harapannya untuk menyimpan peninggalan Sunan Kudus, informasi islamisasi di Kudus, dan benda peninggalan Sunan Kudus. Museum dibangun di kompleks situs Masjid Menara Kudus. Pada bulan Mei 2014 pengerjaan mencapai 95 persen. Bangunan museum berada di sebuah rumah kuno dengan luas museum $14 \mathrm{~m} \times 9 \mathrm{~m}$. Dalam perkembangan renovasi area Masjid dan Menara Kudus, terdapat 8 cungkup atau bangunan pelindung makam di kompleks pemakaman Sunan Kudus direstorasi atau dikembalikan sesuai aslinya dengan material baru. Adapun umpak yang semula diganti dengan cor semen, pada Agustus 2014 diganti dengan batu andesit sebagaimana awalnya dan untuk lantai makam dipesankan dari produsen.

Tokoh islamisasi di wilayah Kudus selain Sunan Kudus adalah Sunan Muria (Raden Umar Said). Silsilah Sunan Muria terdapat ragam versi (1) Sunan Muria putera Sunan Kalijaga, (2) putra Sunan Ngudung, (3) keturunan Arab, (4) keturunan Jawa asli, dan (5) keturunan Cina (Hasyim, 1983). (1) Sunan Muria putera Sunan Kalijaga; Hal ini merujuk tulisan AM Noertjahjo. 1974. Sekitar Walisanga. Pradnya Paramita: Jakarta, Solihin Salam.1974. Sekitar Wali Sanga. Menara Kudus: Kudus, dan Solihin Salam. 1964. Sejarah Islam di Jawa. Jaya Murni: Jakarta. Ketiganya menyatakan bahwa perkawinan Sunan Kalijaga dengan Dewi Saroh binti Maulana Ishaq melahirkan tiga anak, yakni Raden Umar Said (Sunan Muria), Dewi Rukayah, dan Dewi Sofiyah, (2) Sunan Muria putra Sunan Ngudung; R. Darmowasito dalam bukunya Pustoko Darah Agung mencatat silsilah para wali dan raja-raja Jawa bahwa Sunan Muria adalah putera Raden Usman Haji (Sunan Ngudung). Sunan Ngudung pernikahannya dengan Dewi Sarifah melahirkan empat anak, yakni Raden Umar Said (Sunan Muria), Sunan Giri III, Raden Amir Haji (Sunan Kudus), dan Sunan Giri II, (3) Sunan Muria keturunan Arab; Mr.C.L.N van der Berg dalam bukunya De Hadramaut et les Colonies Arabes dans'l Archipel Indien bahwa Sunan Kalijaga dan Sunan Muria adalah keturunan Arab merujuk pada Abdul Muthalib (Kakek Nabi SAW), (4) Sunan Muria keturunan Jawa asli; Tatkala Raden Wijaya (menantu Prabu Kertanegara) dari Singasari melarikan diri dari Singasari didampingi Ranggalawe dan Nambi. Ranggalawe selanjutnya diangkat menjadi Adipati Tuban. Adapun silsilah Sunan Muria terdiri Adipati Ranggalawe (Tuban) yang memiliki anak Ario Tejo I, II (keduanya beragama Syiwa dan makamnya di Tuban ditandai tanda Syiwa, dan III (ketiganya Bupati Tuban) memiliki anak Raden Tumenggung Wilotikto (Bupati Tuban), Raden Mas Said (Sunan Kalijaga), dan Raden Umar Said (Sunan Muria), (5) Sunan Muria keturunan Cina; Slamet Muljana dalam bukunya Runtuhnya Kerajaan Hindu Jawa dan Timbulnya Negara Islam di Nusantara (1968) bersumber dari Mangaraja Panggang Parlindungan dalam buku Tuangku Rao menandaskan bahwa penguasa 
Kerajaan Islam Demak dan di antara anggota wali songo adalah keturunan (peranakan) Cina. Data yang bersumber dari Klenteng Sam Po Kong bahwa Sunan Kalijaga (Gan Sie Cang) merupakan Kapten Tionghoa di Semarang, Sunan Ampel (Bong Swie Hoo), Sunan Kudus (Ja Tik Su), Sunan Gunung Jati (Toh A Bo). Adapun Sunan Bonang, Sunan Giri, dan Sunan Muria merupakan peranakan Cina (Hasyim, 1983:44). Nama kecil Sunan Muria adalah Raden Prawoto. Sunan Muria dalam sejarah lisan dinyatakan berdakwah di wilayah Jepara, Tayu, Juwana, Pati, dan Kudus. Jejak islamisasi di daerah tersebut perlu didalami situs atau peninggalannya. Karyanya untuk berdakwah Sunan Muria antara lain lagu sinom dan kinanti.

Perbedaan silsilah tokoh islamisasi di Jawa tersebut, menurut penulis karena ragam argumen. Pertama, bersumber dari sejarah lisan yang rentan dengan kepentingan penerita karena kedekatan trah. Kedua, penafsiran atas sejarah lisan oleh beberapa penuls. Ketiga, tokoh sering mengganti nama aslinya dengan nama baru karena meninggalkan singgasana. Keempat, nama samaran digunakan oleh tokoh untuk menyembunyikan identias seutuhnya dari diri tokoh.

\section{a. Peninggalan Sunan Muria}

Menentukan umur sebuah benda sejarah dapat memahami artefak peninggalan pelaku sejarah. Masjid Sunan Muria di Gunung Muria, Desa Colo, Kecamatan Dawe, Kabupaten Kudus ditemukan artefak akhir 2009. Ketika masjid direnovasi pada 1970, pada penggalian pondasi untuk pemugaran hingga kini digunakan, banyak ditemukan arang mirip kayu terbakar. Pemugaran masjid, banyak kayu jati yang dimanfaatkan ulang untuk serambi masjid (pawastren) Sunan Muria. Tahun 2009 pawastren direnovasi lagi dan ditemukannya artefak. Penemuan pada sebuah kayu jati yang digunakan penyangga (panuwun) atap masjid yang paling atas peninggalan Sunan Muria. Artefak tertulis TJOEN 4.4.1466 TJEPIRING. Kata tjoen dipahami Pengurus Yayasan Masjid dan Makam Sunan Muria, Mastur merupakan nama etnis China. Angka 4.4 merupakan tanggal dan bulan, 1466 merupakan tahun pembuatan yakni diperkirakan bertepatan pada abad ke15. Kata tjepiring merupakan nama daerah di Kabupaten Kendal penghasil kayu jati.

Peninggalan Sunan Muria berupa mihrab masjid di atasnya terdapat prasasti kaligrafi Arab sebagai istighosah yang diamalkan Sunan Muria, 10 batu lumpak, dan gentong untuk alas/penahan saka masjid. Keberadaan makam dan Masjid Sunan Muria berdiri di atas lahan seluas $4.375 \mathrm{~m}$ di Gunung Muria. Bila ditempuh dengan jalan kaki melewati jalan bertangga/undakan 700 buah. Adapun jarak $500 \mathrm{~m}$ dari halaman parkir peziarah ke lokasi makam.

b. Koleksi Islamisasi di Kudus 
Lantas, di mana museum yang mengoleksi peninggalan sejarah islamisasi di Kudus? Sebut saja cekathak (pelana kuda Sunan Muria) kini tersimpan di 'almari' kompleks makam Sunan Muria (Umar Said), keris cintoko/ciptoko, dan tombak kembar peninggalan Sunan Kudus (Jakfar Shodiq). Benda bersejarah tersebut tertutup untuk publik, sehingga perlu difasilitasi museum dengan pengelola yang profesional. Peninggalan leluhur yang perlu diuri-uri seperti sumur resapan era Sunan Kudus di titik bangunan pawestren (tempat salat di sebelah kanan masjid yang digunakan untuk perempuan yang berjamaah) Masjid Al-Aqsha Menara Kudus.

Benda sejarah merupakan cagar budaya dan kekayaan budaya bangsa sebagai wujud pemikiran dan perilaku kehidupan manusia yang penting artinya bagi pemahaman dan pengembangan sejarah, ilmu pengetahuan, dan kebudayaan dalam kehidupan bermasyarakat, berbangsa, dan bernegara. Hal itu perlu dilestarikan dan dikelola secara tepat melalui upaya perlindungan, pengembangan, dan pemanfaatan dalam rangka memajukan kebudayaan nasional untuk kemakmuran rakyat. Untuk melestarikan cagar budaya (CB), Pemda bertanggung jawab dalam pengaturan perlindungan, pengembangan, dan pemanfaatan $\mathrm{CB}$. CB berupa benda, bangunan, struktur, situs, dan kawasan perlu dikelola oleh pemerintah dan Pemda dengan meningkatkan peran serta masyarakat untuk melindungi, mengembangkan, dan memanfaatkan CB. Dengan adanya perubahan paradigma pelestarian cagar budaya, diperlukan keseimbangan aspek ideologis, akademis, ekologis, dan ekonomis guna meningkatkan kesejahteraan rakyat. Bila museum CB berbasis Islam terwujud, ikon kota santri bagi Kudus kian kokoh. Bagaimana realitanya? Kredo kota santri kian meredup bahkan dimakan ikon baru yakni budaya, kota industry, dan kota kretek. Pemaknaan kota tersebut mengedepankan aspek ekonomi dan budaya. Eksistensi kota santri dengan jargon Gus Jigang (gus: simbol penamaan generasi kiai, Ji: singkatan dari kata ngaji, dan gang singkatan dari kata dagang) yang maknanya bahwa orang Kudus identik dengan kiai, santri, dan pedagang pada tataran riil menjadi 'sebatas' slogan. Di sisi lain, ikon kota penting untuk pencitraan kota yang identik sebagai kota kretek, bukan santri. Kekhasan kota di antaranya dengan dibangunnya simbol kota.

\section{Simpulan}

Bangsa Prancis tatkala Arc de Triomphe selesai dikerjakan tahun 1806, tak banyak yang mengira monumen berbentuk gerbang itu menjadi ikon Kota Paris, bahkan dunia. Warga dunia yang datang tertarik ke lokasi di jantung Kota Paris. Awalnya, momen mengenang pahlawan Prancis, terutama zaman Napoleon Bonaparte (kemudian menjadi makam sejumlah prajurit tak dikenal pada Perang Dunia I). Kemudian menjadi ikon yang sangat memukau. Selain indah, monumen didesain Jean Chalgrin itu dihiasi puluhan patung di empat sisi. Letaknya strategis sehingga mudah dijangkau pelancong dunia. Hal yang sama terjadi pada Menara 
Eiffel dibuka 31 Maret 1889 dibuat memeringati seabad Revolusi Prancis (1789). Banyak negara meniru bentuk menara tetapi tak pernah berhasil, termasuk Menara Tokyo. Eiffel setinggi 330 meter (termasuk antena) didesain arsitek Stephen Sauvestre dan dikerjakan Gustave Eiffel. Karya bersejarah di Perancis lainnya seperti museum peninggalan Napoleon dan Obelisk hadiah dari Mesir hampir seribu tahun silam. Ada juga Place Charles de Gaulle, Avenue Hoche, dan Avenue des Champs-Elysees, De Louvre. Bagitu juga China memiliki Tembok China semasa kaisar pertama China, Qin Shi Huang, dibangun 500 tahun SM sepanjang 6.259 km kini masih gagah di perbukitan. Begitu pula Kota Terlarang (Forbiddean City) dibangun tahun 1406-1420 terdiri 980 bangunan, 720 ribu meter di Kota Beijing, bekas Istana Kaisar (era Dinasti Ming dan Dinasti Qing). Bangunan terbuat dari kayu jati setebal $20 \mathrm{s.d} 60 \mathrm{~cm}$. Spirit terhadap peninggalan yang bersejarah itulah yang perlu diwarisi semangatnya.

Begitu pula upaya membangun anjungan atau Gerbang Kudus Kota Kretek (GKKK) berada di pintu masuk kota Kudus dari arah Kota Demak (arah barat) yang dianggap sebagai simbol kebangkitan industri rokok kretek. Bangunan dengan tinggi 12 meter, lebar 21 meter, dengan material besi baja putih (stainless) direncanakan selesai selama 7 bulan dengan dana Rp 16 miliar dari PT Djarum. Bangunan diduga termegah di Indonesia itu berbentuk daun tembakau dihibahkan pada Pemkab Kudus. Kudus sebagai kota kretek telah diteguhkan dengan dimilikinya museum kretek. Ada pula museum situs purbakala Patiayam untuk destinasi wisata membutuhkan dana Rp 50 miliar. Diawali penemuan gigi pra graham bawah dan pecahan tengkorak manusia, tulang belulang binatang purba pada lapisan batu pasir tufoon oleh Dr.Yahdi Yatim dari Institut Teknologi Bandung (ITB). Pada 1981 ditemukan dua gading gajah purba berukuran 2,5 m dengan diameter $15 \mathrm{~cm}$. Pada 2013 dibuat master plan hingga rencana pembangunan fisik 2015. Situs dirintis sejak 1979 hingga kini telah terkumpul 5 ribu koleksi dari berbagai ukuran. Usia situs temuan mulai dari 700 ribu tahun hingga 1,5 juta tahun seperti gajah purba, harimau dan binatang laut.

Realitas tersebut sebagai penanda bahwa destinasi wisata sebagai bagian dari 'jembatan' menuju terwujudnya sumber ekonomi warga perlu dioptimalkan oleh pemerintah daerah berupa permodalan, pembekalan pengetahuan kepariwisataan, dan kemudahan perizinan. Tujuan utamanya adalah meningkatkan kesejahteraan pelaku wisata. Mulai dari pengusaha yang menyediakan moda transportasi, pengelola hotel dan rumah makan, pedagang kaki lima, pengojek sepeda motor, tukang becak, tukang parkir, dan lainnya. Mata rantai perekonomian tersebut akan tumbuh bila disertai peningkatan kualitas pelayanan pada wisatawan yang dibekali profesionalisme melalui diklat dan penyuluhan. Imbasnya, merawat aset destinasi wisata oleh warga dan pemerintah secara bersama-sama agar sumber perekonomian warga eksis. 
Rosyid

\section{DAFTAR PUSTAKA}

Hasyim, Umar. (1983). Sunan Muria antara Fakta dan Legenda. Menara Kudus: Kudus.

Dewanto, Herpin, (2011). Merangkul Mereka yang Tersisih. Kompas, 18 Mei 2011.

Salam, Solichin. (1986). Ja'far Shadiq Sunan Kudus, cetakan ketiga. Menara Kudus: Kudus. 